\title{
New strategies in hematopoietic stem cell transplantation: G-CSF-mobilized unprocessed whole blood
}

A.M. Dräger,

G.J. Ossenkoppele,

A.R. Jonkhoff,

G.J. Schuurhuis and P.C. Huijgens
Department of Hematology, Free University Hospital,

Amsterdam, The Netherlands

\section{Correspondence \\ A. Dräger \\ Department of Hematology \\ Free University Hospital \\ Brug 248 \\ De Boelelaan 1117 \\ NL-1081 HV Amsterdam \\ The Netherlands \\ Fax: +31-20-4442601 \\ E-mail: hematol@azvu.nl}

Presented at the International Meeting on Cytokines, Angra dos Reis, RJ, Brasil, November 24-28, 1996.

Research supported by AMGEN Holland.

$\ldots \ldots \ldots \ldots \ldots \ldots \ldots$

Received September 4, 1997 Accepted September 22, 1997

\section{Abstract}

Transplantation of mobilized peripheral blood stem cells (PBSC) for rescue of bone marrow function after high-dose chemo-/radiotherapy is widely used in hematologic malignancies and solid tumors. Mobilization of stem cells to the peripheral blood can be achieved by cytokine treatment of the patients. The main advantage of autologous PBSC transplantation over bone marrow transplantation is the faster recovery of neutrophil and platelet counts. The threshold number of PBSC required for adequate rescue of bone marrow is thought to be about $2 \times 10^{6} \mathrm{CD} 34^{+}$cells $/ \mathrm{kg}$, if the stem cells are collected by leukapheresis and subsequently cryopreserved. We show that this critical number could be further reduced to as few as $0.2 \times 10^{6}$ cells $/ \mathrm{kg}$. In 30 patients with multiple myeloma and 25 patients with bad risk lymphoma 1 liter of granulocyte colony-stimulating factor (G-CSF)mobilized unprocessed whole blood (stored at $4^{\circ} \mathrm{C}$ for 1-3 days) was used for transplantation. Compared to a historical control group, a significant reduction in the duration of neutropenia, thrombocytopenia and the length of hospital stay was documented. Furthermore, the effect of stem cell support was reflected by a lower need for platelet and red cell transfusions and a reduced antibiotic use. Considering the data as a whole, a cost saving of about $50 \%$ was achieved. To date, this easy to perform method of transplantation is only feasible following high-dose therapies that are completed within $72 \mathrm{~h}$, since longer storage of unprocessed blood is accompanied by a substantial loss of progenitor cell function. Ongoing investigations include attempts to prolong storage times for whole blood.

\section{Mobilization of hematopoietic stem cells}

Dührsen et al. (1) were the first to demonstrate that administration of recombinant granulocyte colony-stimulating factor (GCSF) increases the number of colony-forming units in peripheral blood up to 100 -fold steady-state levels. In normal individuals the
Key words

- Hematopoietic stem cells

- Transplantation

- Cytokines

- G-CSF

- Lymphoma

- Multiple myeloma number of mobilized peripheral blood stem cells (PBSC) depends on the dose of G-CSF used (5-15 $\mu \mathrm{g} / \mathrm{kg}, \mathrm{sc}, 4-6$ days, daily (2) or twice daily (3)) and the age of the donor, whereas the stem cell yield in patients who have been previously subjected to therapy strongly depends on the number of courses of chemotherapy or radiotherapy (4-6). Recently, the advantages of G-CSF-mobilized 
peripheral blood progenitor transplantation vs autologous bone marrow transplantation were demonstrated in a randomized trial in patients with lymphoma treated with highdose chemotherapy (7). The number of platelet transfusions, the time to neutrophil recovery and the period of hospital stay were significantly reduced.

To date, other agents with the potential to mobilize stem cells but which have not yet been tested in clinical trials include GM-CSF, stem cell factor (8,9), IL-8 (10), IL-3, IL-6, IL-11 (11), and antibodies directed against the adhesion molecule VLA-4 (CD49d). Apart from cytokines, the number of circulating PBSC can be increased by chemotherapy during hematopoietic recovery as originally observed by Richman et al. (12). However, the stem cells harvested contain a smaller portion of primitive progenitor cells compared to GCSF alone, as measured by the the lack of HLA-DR or CD38 in the CD34+ cell population. In addition, a combination of cytokine administration following chemotherapy has been reported to effectively mobilize stem cells (reviewed in Ref. 13).

Patients in whom stem cells are poorly mobilized have to undergo several cycles of leukapheresis to collect enough stem cells for long-term repopulation of the bone marrow. The threshold number of PBSC required for adequate rescue of bone marrow is about $2 \times 10^{6} \mathrm{CD} 34^{+}$cells $/ \mathrm{kg}$ (reviewed in Ref. 13), if the stem cells are collected and cryopreserved. During cryopreservation loss of quality of the transplant may occur, since we could show that the critical number of stem cells for rescue could further be reduced to as few as $0.2 \times 10^{6}$ cells $/ \mathrm{kg}$ if 1 liter of mobilized unprocessed whole blood was reinfused (14-16).

Clinical studies involving G-CSFmobilized unprocessed whole blood

Studies by Molineux et al. (17) showed that the amount of blood required to rescue lethally irradiated mice could be reduced from $3 \mathrm{ml}$ (1.5 times the normal blood volume) to $10 \mu \mathrm{l}$ when using blood of mice which were pretreated with G-CSF. Furthermore, it was shown that blood of G-CSF-treated mice contained hematopoietic stem cells functionally comparable to bone marrow-derived stem cells (18). The authors presumed that about $5 \mathrm{ml}$ of stimulated unprocessed blood/kg body weight may be sufficient for successful engraftment in humans. We tested the feasibility of unprocessed blood treatment first in a small group of patients $(\mathrm{N}=5)$ with multiple myeloma receiving high-dose melphalan (HDM; 140 $\mathrm{mg} / \mathrm{m}^{2}$ ) at day $0(14)$. To date, the study has been extended to more than 30 patients (16). In this study, $10 \mu \mathrm{g} / \mathrm{kg}$ G-CSF (filgrastim; Neupogen Amgen, Thousand Oaks, CA, USA) was administered sc daily starting on day -6 for 6 days. On day 0 , two phlebotomies of 500 $\mathrm{ml}$ each were performed via an antecubital vein and melphalan was given intravenously. After $24 \mathrm{~h}$ the two bags of blood were reinfused. The median number of $\mathrm{CD} 34^{+}$cells in blood after mobilization was $0.3 \times 10^{6} / \mathrm{kg}$ (range 0.1-1.75). Compared with a historical control group of 20 patients treated with HDM without stem cell rescue, the median duration of neutropenia was reduced by 24 days, the median duration of thrombocytopenia by 10 days and the median length of hospital stay by 24 days. The effect of stem cell support was also reflected by a lower need for platelet and red cell transfusions and a reduced antibiotic use. Besides reduced toxicity, a cost saving of about $50 \%$ was calculated (19).

In another study (15) the whole blood stem cell procedure was adapted to a modified (72-h course) myeloablative BEAMlike scheme in 9 patients with bad risk malignant lymphomas. In this treatment protocol the blood was stored unprocessed for 3 days at $4^{\circ} \mathrm{C}$ before reinfusion. The scheme was adjusted in such a way that the cytostatics used had been largely cleared from the blood by the day of reinfusion. The median number of reinfused $\mathrm{CD}^{2} 4^{+}$stem cells was $0.28 \mathrm{x}$ 
$10^{6} / \mathrm{kg}$ (range 0.01-0.59). When more than $0.2 \times 10^{6} / \mathrm{kg} \mathrm{CD} 4^{+}$cells were reinfused the time to recovery was comparable to that observed after classical peripheral stem cell transplantation (15).

Liquid storage of peripheral blood progenitors

To date we only employ this attractive method of autologous stem cell transplantation using 1 liter of unprocessed whole blood if high-dose chemotherapy is completed within $72 \mathrm{~h}$ since longer storage of unprocessed blood is accompanied by a substantial loss of progenitor cells. We could show that the number of $\mathrm{CD}_{3} 4^{+}$cells in blood from G-CSF-treated patients with lymphoma even increased in 12/20 patients after 3 days of storage at $4^{\circ} \mathrm{C}$ as compared to day 0 . Storage at $24^{\circ} \mathrm{C}$ resulted in a reduced number of progenitor cells after 3 days. Studies on the feasibility of storage for longer periods of time were hampered by the fact that only small amounts of blood were still available after reinfusion of the bulk on day 3. Comparing the quality of progenitor cells during the first 3 days, we found better results when the blood was stored in a larger volume compared to a smaller volume. Improvement of the storage conditions is necessary to extend the whole blood procedure to other chemotherapeutic regimens. The addition of G-CSF at a concentration of 10 $\mathrm{ng} / \mathrm{ml}$ to cells in storage showed no detectable benefit (20). In this study, $77 \%$ of the initial colony-forming units remained after $96 \mathrm{~h}$ at $4^{\circ} \mathrm{C}$. Our findings are also in accordance with the study of Pettengell et al. (21) who established that hematopoietic progenitors in leukapheresis material and in whole blood remain viable for 5 days at $4^{\circ} \mathrm{C}$. The use of non-cryopreserved mobilized blood stem cells has also been described by others $(22,23)$. In these studies, however, leukapheresis material was used.
Role of adhesion molecules in the mobilization of stem cells and their homing to bone marrow

Although the underlying mechanisms of mobilization are largely unknown, it is evident that adhesion molecules play a crucial role in this process. Mobilization may be the result of downregulation of adhesion molecules on stem cells which would enable these cells to be recruited with increased efficacy into the peripheral blood. Candidate adhesion molecules are LFA-1, VLA-4, VLA- 5 and LFA-3 since these molecules are expressed in lesser amounts on PBSC as compared to their bone marrow counterparts (24-26).

On the other hand, the expression of these cell surface markers on stem cells can be expected to be important for effective engraftment after reinfusion. Important structures involved in the 'homing' of PBSC to the bone marrow include the selectin family of adhesion molecules and their glycoprotein ligands. Blood-derived stem cells express high levels of CD62L (L-selectin) as compared to bone marrow stem cells (24). This observation may explain the improved kinetics of bone marrow recovery after PBSC transplantations, since it has been described that the number of reinfused $\mathrm{CD} 34^{+} / \mathrm{CD} 62 \mathrm{~L}^{+}$ stem cells correlates better with the time needed for platelet recovery than the total number of $\mathrm{CD}^{+} 4^{+}$cells (25). On the other hand, it has been shown that neutrophils stimulated with G-CSF upregulate CD11b/ CD18 but partly shed their L-selectin receptor (27). Furthermore, G-CSF directly stimulates neutrophil migration across the vascular endothelium (28). It has to be further evaluated whether all of these observations hold true not only for neutrophils but also for stem cells. These observations would be consistent with the role of G-CSF in the mobilization of cells from marrow stores. 


\section{References}

1. Dührsen U, Villeval JL, Boyd J, Kannourakis G, Morstyn G \& Metcalf D (1988). Effects of recombinant human granulocyte colony-stimulating factor on hematopoietic progenitor cells in cancer patients. Blood, 72: 2074-2081.

2. Dreger $P$, Haferlach $T$, Eckstein $V$, Jacobs S, Suttrop M, Löffler H, Müller-Ruchholz W \& Schmitz N (1994). G-CSF mobilized peripheral blood progenitor cells for allogenic transplantation: safety, kinetics of mobilization, and composition of the graft. British Journal of Haematology, 87: 609613.

3. Waller CF, Bertz $H$, Wenger MK, Fetscher S, Hardung M, Engelhardt M, Behringer D, Lange W, Mertelsmann R \& Finke J (1996). Mobilization of peripheral blood progenitor cells for allogenic transplantation: efficacy and toxicity of a high-dose rhG-CSF regimen. Bone Marrow Transplantation, 18: 279-283.

4. Dreger $P$, Klöss $M$, Petersen $B$, Haferlach T, Löffler H, Loeffler M \& Schmitz N (1995). Autologous progenitor cell transplantation: prior exposure to stem cells toxic drugs determines yield and engraftment of peripheral blood progenitor cells but not of bone marrow grafts. Blood, 86 : 3970-3978.

5. Haas R, Möhle R, Fruhauf $S$, Goldschmidt $H$, Witt B, Flentje M, Wannenmacher M \& Hunstein W (1994). Patient characteristics associated with successful mobilizing and autografting of peripheral blood progenitor cells in malignant lymphoma. Blood, 83: 3787-3794.

6. Tricot G, Jagannath $S$, Vesole D, Nelson J, Tindle S, Miller L, Cheson B, Crowley J \& Barlogie B (1995). Peripheral blood stem cell transplants for multiple myeloma: identification of favorable variables for rapid engraftment in 225 patients. Blood, 85: 558-596.

7. Schmitz N, Linch DC, Dreger P, Goldstone $A H$, Boogaerts MA, Ferrant A, Demuynck HM, Link H, Znader A, Barge A \& Borkett K (1996). Randomised trial of filgrastim mobilised peripheral blood progenitor cell transplantation versus autologous bonemarrow transplantation in lymphoma patients. Lancet, 347: 353-357.
8. Andrews RG, Briddell RA, Knitter GH, Opie T, Bronsden M, Myerson D, Appelbaum FR \& McNiece IK (1994). In vivo synergy between recombinant human stem cell factor and recombinant human granulocyte colony-stimulating factor in baboons: enhanced circulation of progenitor cells. Blood, 84: 800-810.

9. Yan XQ, Hartley C, McElroy P, Chang A, McCrea C \& McNiece I (1995). Peripheral blood progenitor cells mobilized by recombinant human granulocyte colonystimulating factor plus recombinant rat stem cell factor contain long-term engrafting cells capable of cellular proliferation for more than two years as shown by serial transplantation in mice. Blood, 85: 2303-2307.

10. Fibbe W (1995). Interleukin-8 induces rapid mobilization of hematopoietic stem cells with radioprotective capacity and long term myelolymphoid repopulating ability. Blood, 85: 2269-2275.

11. Nemunaitis J (1996). Cytokine-mobilized peripheral blood progenitor cells. Seminars in Oncology, 23: 9-14.

12. Richman $C M$, Weiner RS \& Yankee RA (1976). Increase in circulating stem cells following chemotherapy in man. Blood, 47: 1031-1039.

13. Haas R \& Murea $S$ (1995). The role of granulocyte colony-stimulating factor in mobilization and transplantation of peripheral blood progenitor and stem cells. $\mathrm{Cy}$ tokines and Molecular Therapy, 1: 249270.

14. Ossenkoppele GJ, Jonkhoff AR, Huijgens PC, Nauta JJP, van der Hem KG, Dräger AM \& Langenhuijsen MMAC (1994). Peripheral blood progenitors mobilised by GCSF (filgrastim) and reinfused as unprocessed autologous whole blood shorten the pancytopenic period following highdose melphalan in multiple myeloma. Bone Marrow Transplantation, 13: 37-41.

15. Ossenkoppele GJ, Schuurhuis GJ, Jonkhoff AR, Dräger AM, Westra G, Oberink JW, Legdeur MCJC, Kreuk AM de, Zweegman S \& Huijgens PC (1996). G-CSF (filgrastim)-stimulated whole blood kept unprocessed at $4{ }^{\circ} \mathrm{C}$ does support a BEAM-like regimen in bad-risk lymphoma. Bone Marrow Transplantation, 18: 427431.
16. Ossenkoppele GJ, Schuurhuis GJ, Jonkhoff AR, van der Hem KG, Legdeur MCJC, Boot-Bakker A, Westra AH, Dräger AM \& Huijgens PC (1996). High dose melphalan with re-infusion of unprocessed G-CSF primed whole blood is effective and non-toxic therapy in multiple myeloma. European Journal of Haematology, 32A: 2058-2063.

17. Molineux G, Pojda Z, Hampson IN, Lord BI \& Dexter TM (1990). Transplantation potential of peripheral blood stem cells induced by granulocyte colony-stimulating factor. Blood, 76: 2153-2158.

18. Demuynck $H$, Pettengell $R$, De Campos E, Dexter TM \& Testa NG (1992). The capacity of peripheral blood stem cells mobilised with chemotherapy plus G-CSF to repopulate irradiated marrow stroma in vitro is similar to that of bone marrow. European Journal of Cancer, 28: 381-386.

19. Uyl-Groot CA, Huijgens PC \& Rutten FFH (1996). Colony-stimulating factors and peripheral blood progenitor cell transplantation. PharmacoEconomics, 10: 23-35.

20. Jestice HK, Scott AM, Ager S, Tolliday BH \& Marcus RE (1994). Liquid storage of peripheral blood progenitor cells for transplantation. Bone Marrow Transplantation, 14: 991-994.

21. Pettengell R, Woll PJ, O'Connor DA, Dexter TM \& Testa NG (1994). Viability of haemopoietic progenitors from whole blood, bone marrow and leukapheresis product: effects of storage media, temperature and time. Bone Marrow Transplantation, 14: 703-709.

22. Ager $S$, Mahendra $P$, Jestice HK, Scott M \& Marcus RE (1995). The use of noncryopreserved peripheral blood progenitor cells in autologous transplantation. Bone Marrow Transplantation, 16: 633634.

23. Ruiz-Argüelles GJ, Ruiz-Argüelles $A$, Pérez-Romano B, Marín-López A, Larregina-Díez A \& Apreza-Molina MG (1995). Filgrastim-mobilized peripheral-blood stem cells can be stored at 4 degrees and used in autografts to rescue high dose chemotherapy. American Journal of Hematology, 48: 100-103. 
24. Möhle R, Murea S, Kirsch M \& Haas R (1995). Differential expression of L-selecting, VLA-4 and LFA-1 on CD34+ progenitor cells from bone marrow and peripheral blood during G-CSF enhanced recovery. Experimental Hematology, 23: 15351542.

25. Dercksen MW, Gerritsen WR, Rodenhuis S, Dirkson MK, Slaper-Cortenbach IC, Schaasberg WP, Pinedo HM, von dem Borne AE \& van der Schoot CE (1995). Expression of adhesion molecules on $\mathrm{CD}^{+} 4^{+}$cells: $\mathrm{CD} 34^{+} \mathrm{L}_{\text {-selectin }}{ }^{+}$cells predict a rapid platelet recovery after peripheral blood stem cell transplantation. Blood, 5: 3313-3319.
26. Turner ML, Mcllwaine K, Anthony RS \& Parker AC (1995). Differential expression of cell adhesion molecules by human hematopoietic progenitor cells from bone marrow and mobilized adult peripheral blood. Stem Cells, 13: 311-316.

27. Yong KL \& Linch DC (1992). Differential effects of granulocyte and granulocytemacrophage colony-stimulating factor (Gand GM-CSF) on neutrophil adhesion in vitro and in vivo. European Journal of Haematology, 49: 251-259.
28. Yong KL (1996). Granulocyte colonystimulating factor (G-CSF) increases neutrophil migration across vascular endothelium independent of an effect on adhesion: comparison with granulocyte-macrophage colony-stimulating factor (GMCSF). British Journal of Haematology, 94: 40-47. 